DOI https://doi.org/10.30525/978-9934-588-90-7-31

\title{
CONNOTATION OF LEXICAL SEMANTIC FIELD IN AUTHOR'S LITERARY TEXT
}

\author{
Holovashchenko Yu. S. \\ Candidate of Philology, \\ Assistant at the Chair of Communicative Linguistics and Translation Studies \\ Yuriy Fedkovych Chernivtsi National University \\ Chernivtsi, Ukraine
}

On the threshold of the 21 st century the phenomenon of a literary text has witnessed a significant evolution in terms of its interpretation and possibilities of research [19]. A literary text is not only regarded as a 'langue' system, which dwells on the static nature of any text as a unity of language units [17]. A literary text can nowadays be approached with more diverse multidisciplinary interpretations, such as the foundations of its fictionality $[10 ; 15 ; 16]$; the communicative message it expresses [2]; the correlation of style, genre and language means of their expression $[12 ; 13 ; 16]$ the nature of discourse and its "power" on the process of text creation $[11 ; 19 ; 21]$.

However, one of the key aspects of a literary text is its close connection to an author, which accentuates the anthropocentric nature of both language and text. Any literary text is inalienable from its author whose literary vision is inherently incorporated in specific language use. Thus, a literary text should be viewed as distinctive reflection of the author's individuality on the macrolevel of text structure as well as microlevel of particular word selection.

The starting point of "deciphering" the author's presence in his literary text is the notion of language world picture, which refers to human collective knowledge of the world represented in language $[6$, p. $70 ; 7$, p. 23]. The author's experience of knowledge formation is exceptionally individual as it is for any other person. Thus, his knowledge can be characterized as individual author's language picture of the world, which is palpable through the linguistic level of his text.

According to D. Lodge, "the novelist's medium is language: whatever he does, qua novelist, he does in and through language" [14, p. xiii]. H. Vynokur also asserts that the sense of a literary text lies in correlation of direct word meanings and its larger meaning, i.e. its theme [3, p. 53]. Therefore, the author's stance in language can be effectively studied on the lexical level of a literary text, which suggests introducing the notion of a lexical semantic field $[4$, p. 71$]$ for further research. 
First and foremost, a lexical semantic field in the framework of a literary text implies the structured unity of words, or lexical units, based on their meaning $[1$, p. 175]. The prerequisite of its structured-ness lies exactly in the author's literary presence in text, which means accordance of lexical selection and word meanings to his literary idea. Additionally, lexical semantic fields, sketching the dominant semantic spaces, correlate with some other aspects of the author's literary text, such as individual-style-related (predominant themes, generic peculiarities, and sense creation techniques [8, p. 7]) and generic features.

The genre of a literary text lies on the border of both Linguistics and Literary Studies, with each field of study focusing on different characteristics of it. However, a brand new approach is to bring Literary Theory contributions into Linguistics and examine how the specific genre can be traced on the lexical level of the author's literary text, which constitutes the novelty of the research.

The material of research is the novel "Dusklands" by John Maxwell Coetzee, an outstanding South African-born writer and 2003 Nobel Prize in Literature recipient. Literary works and novels by J. M. Coetzee represent postcolonial philosophy and are, accordingly, examples of postcolonial literary legacy.

The aim of the article is to outline how the theme of a literary text correlates with a lexical semantic field in order to express its connotative potential in the literary context.

Literary works of J. M. Coetzee echo some characteristic themes of the genre of a postcolonial novel, which have been identified as generic-thematic features and labeled as representation of ambivalent postcolonial consciousness, repercussion of imperial regime in postcolonial society, social recontextualization, and centralization of marginal regions [4, pp. 49-50]. The individual feature of J. M. Coetzee's novels is regarded as social and individual alienation $[4$, p. 60]. The abovementioned features correlate with the lexical stratum of J. M. Coetzee's novels as literary texts and result in "rethinking" of lexical structures as thematically oriented.

The lexical semantic field "Human Body", centralizing semantics of "relation to human body", is reconsidered in "Dusklands" through juxtaposing physical and emotional suffering. The thematic feature of ambivalent postcolonial consciousness in "Dusklands" comes into vision when the idea of body is used to show inner pain that does not exist outside. The following example illustrates this point: "Inside my body, beneath the skin and muscle and flesh that drape me, I am bleeding. Sometimes I think the wound is in my stomach, that it bleeds slime and despair over the food that should be nourishing me, seeping in the little puddles that rot the crooks of my obscurer hooked organs. At the other times I imagine a wound weeping somewhere in 
the cavern behind my eyes. There is no doubt that I must find and care for it, or else die of it. That is why I have no shame about unveiling myself" $[9$, p. 32]. On the one hand, the pain of the wound that the hero is talking about is possible to fathom; yet the wound is metaphoric and can be rather interpreted as inner anguish chasing the hero and making it hard for him to suppress it.

Another example illustrates the same point: "Dull dreams in a dull bed. Marilyn floats face down through my nights. I chop in my hook and pull. Flesh flakes off bloodless and she floats away. I touch my fingers to her arm, warmer asleep than awake, cell packed against cell in an ecstasy of hibernation. The man in the tiger cage flashes a black eye at me. I stretch out my hand" [9, p. 34]. The theme of ambivalent postcolonial consciousness relocates the focus from the body as physical constitution to the body as a means of hallucination-stricken vision of reality, thus, making the hero completely lost in the labyrinth of dreams and real life. Furthermore, the lexis for body conveys the theme of social and individual alienation, as the hero in his dream has an estranged interaction with a floating body-shaped object.

In conclusion, the role lexical semantic field in the author's literary text can be viewed in terms of the connotative effect it acquires in the narrow context. On the one hand, the individuality of the author plays a significant part in the lexical structure of the literary text. On the other hand, the thematic component of the genre induces specific sense-related implications for lexical meanings. On a bigger scale, lexical units serve to express the thematic potential of the literary text while being fragmentarily used in micro-context environment.

The further research can be suggested to develop the mechanism of sensemaking in the context of the author's literary text as well as focus on the works of other representatives of postcolonial literature.

\section{References:}

1. Безкоровайная Г. Т. Семантические поля как способ систематизации лексических единиц: попытка обобщения основных положений теории поля. Вісник Дніпропетровського університету імені Альфреда Нобеля. Серія ,, Філологічні науки”. 2012. № 1(3). С. 172-180.

2. Болотнова Н. С. Филологический анализ текста: учеб. пособие. 4-е изд. Москва: Флинта: Наука, 2009. 520 с.

3. Винокур Г. О. О языке художественной литературы: Учеб. пособие для филол. спец. вузов. / Сост. Т. Г. Винокур; Предисл. В. П. Григорьева. Москва: Высшая школа, 1991. 448 с. 
4. Головащенко Ю. С. Семантичний простір романів Джона Мексвелла Кутзее: автореф. дис. ... канд. філол. наук: 10.02.04. Чернівці, 2018. $20 \mathrm{c}$.

5. Кухаренко В. А. Интерпретация текста: Учеб. пособие для студентов пед. ин-тов по спец. № 2103 «Иностр. яз.». 2-е изд., перераб. Москва: Просвещение, 1988. 192 с.

6. Маслова В. А. Когнитивная лингвистика: учеб. пособие. 3-е изд., перераб. и доп. Минск: ТетраСистемс, 2008. 272 с.

7. Приходько А. М. Концепти і концептосистеми в когнітивнодискурсивній парадигмі лінгвістики. Запоріжжя: Прем'єр, 2008. 332 с.

8. Тарасова И. А. Поэтический идиостиль в когнитивном аспекте: монография. 2-е изд., перераб. Москва: ФЛИНТА, 2012. 196 с.

9. Coetzee J. M. Dusklands. New York: Penguin Books, 1985. 127 p.

10. James H. The Art of Fiction. Essentials of the Theory of Fiction / Ed. Michael J. Hoffman, Patrick D. Murphy. $3^{\text {rd }}$ edition. Durham: Duke University Press, 2005. P. 13-20.

11. Johansen J. D. Literary Discourse: A Semiotic-pragmatic Approach to Literature. Toronto: University of Toronto Press, 2002. 489 p.

12. Kent T. Interpretation and Genre: The Role of Generic Perception in the Study of Narrative Texts. Lewisburg: Bucknell University Press, 1986. 180 p.

13. Language, Discourse and Literature: An Introductory Reader in Discourse Stylistics / Edited by Ronald Carter and Paul Simpson. London: Routledge, 2003. 304 p.

14. Lodge D. Language of Fiction: Essays in Criticism and Verbal Analysis of the English Novel. New York: Psychology Press, 2002. 323 p.

15. Matravers D. Fiction and Narrative. Oxford: Oxford University Press, 2014. 169 p.

16. Modern Genre Theory / edited and introduced by D. Duff. London; New York: Routledge, 2014. 304 p.

17. Ronen R. Possible Worlds in Literary Theory. Cambridge: Cambridge University Press, 1994. 244 p.

18. Thibault P. J. Re-reading Saussure: The Dynamics of Signs in Social Life. Routledge, 2013. 384 p.

19. Van Dijk T. A. Discourse and Context: A Sociocognitive Approach. New York: Cambridge University Press, 2008. 220 p.

20. Wetherill P. M. The Literary Text: An Examination of Critical Methods. Berkeley; Los Angeles: The University of California Press, 1974. $331 \mathrm{p}$.

21. Widdowson H. G. Text, Context, Pretext: Critical Issues in Discourse Analysis. Oxford: Blackwell Publishing, 2004. 185 p. 